\title{
Association of 5-HT2C (rs3813929) and UCP3(rs 1800849) gene polymorphisms with type 2 diabetes in obese women candidates for bariatric surgery
}

1 Universidade Estadual Paulista Júlio de Mesquita Filho (Unesp), Programa de Pós-Graduação em Alimentos e Nutrição, Araraquara, SP, Brasil

2 Universidade Metodista de Piracicaba (Unimep), Programa de Pós-Graduação em Ciências do Movimento Humano,

Piracicaba, SP, Brasil

${ }^{3}$ Unesp, Faculdade de Medicina, Botucatu, SP, Brasil

${ }^{4}$ Clínica Bariátrica,

Piracicaba, SP, Brasil

\section{Correspondence to:}

Maria Rita Marques de Oliveira Universidade Estadual Paulista (Unesp), Instituto de Biociências. Distrito de Rubião Junior, s/n, caixa postal 510

18618-000 - Botucatu, SP, Brasil

mrmolive@ibb.unesp.br

Received on April/17/2016

Accepted on Nov/25/2016

DOl: 10.1590/2359-3997000000260
Noa Pereira Prada Schnor', Rozangela Verlengia², Patrícia Fátima

Sousa Novais', Alex Harley Crisp', Celso Vieira de Souza Leite³, Irineu Rasera-Júnior', Maria Rita Marques de Oliveira'

\begin{abstract}
Objective: Obesity can cause systemic arterial hypertension (SAH) and type 2 diabetes mellitus (DM2) factor that is also influenced by genetic variability. The present study aims to investigate the association between gene polymorphisms related with obesity on the prevalence of SAH and DM2 in the preoperative period and 1 year after Roux-en-Y gastric bypass surgery. Subjects and methods: In total, 351 obese women in a Brazilian cohort completed the study. The clinical diagnosis of SAH and DM2 was monitored from medical records. Twelve gene polymorphisms (rs26802; rs572169; rs7799039; rs1137101; rs3813929; rs659366; rs660339; rs1800849; rs7498665; rs35874116; rs9701796; and rs9939609) were determined using real-time polymerase chain reaction and TaqMan assay. Results: In the preoperative period, prevalence of SAH and DM2 was $57 \%$ and $22 \%$, respectively. One year postoperatively, $86.8 \%$ subjects had remission of DM2 and $99.5 \%$ had control of SAH. Subjects with T allele from the serotonin receptor gene (5-HT2C, rs3813929) had five times greater chance of DM2, and the CC genotype from uncoupling protein 3 gene (UCP3, rs1800849) had three times greater chance in the preoperative period. Conclusion: These findings indicate that polymorphisms rs3813929 and rs1800849 from 5-HT2C and UCP3 genes were related to DM2 prevalence among the Brazilian obese women candidates for bariatric surgery. Arch Endocrinol Metab. 2017;61(3):326-31.
\end{abstract}

Keywords

Obesity; type 2 diabetes; hypertension; gene polymorphism

\section{INTRODUCTION}

$\mathrm{O}$ besity prevalence is increasing at a worrying rate; with significant influence on morbidity and mortality rate worldwide (1). Excessive food intake and a sedentary lifestyle contribute to the accumulation of body fat and increase the risk of chronic diseases such as systemic arterial hypertension (SAH) and type 2 diabetes mellitus (DM2) (2). Moreover, genetic factors are recognized as an important influence in increasing susceptibility to obesity and its associated comorbidities (3).

A genetic factor of considerable interest is the variation of a gene (DNA sequence bases) between subjects, described as gene polymorphism (4). In this context, some studies have related polymorphism of specifics genes that control appetite, energy metabolism, susceptibility to obesity (5), and chronic diseases such as DM2 and SAH (6).
It is recognized that obesity and its associated comorbidities have multifactorial causes. Therefore, it is important to analyze several genes and the interaction between them to better understand the obesity genesis and the contribution of genetic variability. Review studies indicate a large number of gene candidates that may be related to obesity and chronic diseases (7-9).

Regarding the treatment of obesity, bariatric surgery is the most long-term effective method of inducing body weight loss and beneficial effects on metabolic disorders (10). However, there is a significant variability in body weight loss and control of comorbidities between subjects undergoing bariatric surgery (11). This suggests that some of these variable responses to bariatric surgery can be explained by genetic factors.

In this sense, investigating the relationship between uncoupling protein 3 (UCP3) gene polymorphism 
(rs1800849) and results after biliopancreatic diversion surgery (BDS), Luis and cols. (12) observed no significant association with the control of SAH and DM2 1 year postoperatively. However, another study from Luis and cols. (13) indicated that fat mass and obesityassociated (FTO, rs9939609) gene polymorphism were associated with greater body weight loss 3 months after BDS, but no difference was evident after 9 and 12 months postoperatively. In addition, Luis and cols. (13) observed an association between FTO gene polymorphism (rs9939609) with a decrease in the body mass index (BMI), and improvements of glycated hemoglobin ( $\mathrm{HbAlc}$ ) levels 6 months after mini gastric bypass laparoscopic surgery. Therefore, other studies are warranted to investigate a larger number of gene polymorphisms to expand the evidence regarding the effect of genetic variability as a determinant of SAH and DM2 on obesity and bariatric surgery response.

The main benefit of surgical treatment of obesity is the control of comorbidities. Therefore, the current study selected 12 gene polymorphisms related to obesity in order to assess an association with SAH and DM2 prevalence, and the possible influence on bariatric surgery results. There is some evidence that suggests effects on the prevalence of DM2 with polymorphisms of ghrelin (GHRL, rs26802), uncoupling protein 2 (UCP2, rs659366), uncoupling protein 3 (UCP3, rs1800849), FTO (rs9939609), leptin (LEP, rs7799039), leptin receptor (LEPR, rs1137101), and serotonin receptor (5-HT2C, rs3813929) genes.

Thus, the current study aimed to investigate the association of 12 gene polymorphisms on the prevalence of SAH and DM2 in the preoperative period and 1 year after Roux-en-Y gastric bypass (RYGB) surgery in obese women.

\section{SUBJECTS AND METHODS}

This is a prospective study with adult women undergoing RYGB surgery, performed by the same medical staff from June 2010 to May 2013. The subjects were evaluated in the preoperative period and 1 year postoperatively. Self-reported information regarding age, skin color, education, previous pregnancies, family history of obesity, and obesity at early age was recorded. Body weight, BMI, and the presence of SAH and DM2 were provided by medical records.

The eligible criteria for participation were: (a) being female; (b) aged between 20 and 50 years; (c) and registered on the waiting line for bariatric surgery. The exclusion criteria were as follows: (a) alcoholism; (b) genetic syndromes associated with obesity; (c) Cushing's syndrome; (d) hypothyroidism; (e) renal or liver failure; (f) neoplasia; (g) infection with human immunodeficiency virus (HIV); (h) use of corticosteroids; (i) and postmenopausal women using estrogen replacement.

In total, 441 women in a Brazilian cohort were eligible for study inclusion. However, subjects who did not attend 1 year postoperatively were not included in data analysis. This study included 351 subjects who completed the study. The number of subjects was determined using the data of the genotype with lower prevalence and a minimum 300 subjects was shown to be necessary. All subjects signed a free-andinformed consent form after being informed about the procedures involved in the research. This study was approved by the local Research Ethics Committee (protocol number: 3303/2009).

Body weight was measured using a digital balance (Fizola, SP, Brazil) with a capacity of $200 \mathrm{~kg}$, precise to within $100 \mathrm{~g}$. Height measurements were obtained using a stadiometer (Seca, SP, Brazil) precise to within $0.1 \mathrm{~cm}$. The procedures followed the standard recommendations (14). Excess weight (EW, in $\mathrm{kg}$ ); weight loss (WL, in $\mathrm{kg}$ ), and percentage of excess weight loss (\%EWL), were calculated using the followings formulas (15):

$\mathrm{EW}=$ body weight preoperatively - ideal body weight;

WL = body weight preoperatively - current body weight;

$\% E W L=$ percentage of body weight lost in relation to excess weight.

The SAH remission was considered when the subject stopped with anti-hypertensive medications and presented: systolic blood pressure $<140 \mathrm{mmHg}$ and diastolic blood pressure $<90 \mathrm{mmHg}$ (16). The DM2 remission was considered when the subject stopped with anti-diabetic medications and presented: fasting glucose concentration < $126 \mathrm{mg} / \mathrm{dL}$; postprandial glucose $<200 \mathrm{mg} / \mathrm{dL}$ after $75 \mathrm{~g}$ oral glucose load, and hemogloblin Alc level < 6.5\% (17).

Genomic DNA was isolated from whole blood samples (EDTA-treated), using Illusta blood genomicPrep Kit (GE Healthcare ${ }^{\circledR}$ New York, USA). The analysis of gene polymorphisms GHRL (rs26802); GHRS (rs572169); LEP (rs7799039); LEPR (rs1137101); 5HT2C (rs3813929); UCP2 
(rs659366); UCP2 (rs660339); UCP3 (rs1800849); SH2BI (rs7498665); TAS1R2 (rs35874116); TAS1R2 (rs9701796); and FTO (rs9939609), was determined by real-time polymerase chain reaction (RT-PCR) and TaqMan assay (Applied Biosystems ${ }^{\circledR}$, Branchburg, New Jersey, USA). The RT-PCR was processed in ABI 7500 fast equipment (Applied Biosystems ${ }^{\circledR}$, Branchburg, NJ, USA) according to the manufacturer's instructions. A random selection of $10 \%$ of the samples was again genotyped to evaluate the reproducibility of genotyping.

The agreement of genotype frequencies with Hardy-Weinberg equilibrium expectations was tested by chi-square test. Multiple logistic regressions were performed to evaluate the effects of gene polymorphism (with adjustments for age, skin color, preoperative BMI, previous pregnancy, and age at onset of obesity) taking SAH and DM2 as dependent variables. When the genotype of lower frequency was $<10 \%$, the genotype was combined with a heterozygous genotype. $p<0.05$ was considered to be statistically significant.

\section{RESULTS}

The genotype distributions of gene polymorphisms (rs26802; rs572169; rs7799039; rs1137101; rs3813929; rs659366; rs660339; rs1800849; rs7498665; rs35874116; rs9701796; rs9939609) was within the expectations of the Hardy-Weinberg equilibrium $(p>0.05)$. Table 1 shows characterization of the study subject.

One year postoperatively, of 76 subjects with DM2, only 10 maintained the diagnosis of DM2, representing a control of $86.8 \%$. Regarding SAH, $99.5 \%$ of subjects had control of this disease. The median of $\% \mathrm{EWL}$ was $69.2 \%$; of which $4.3 \%$ of the subjects had less than $50 \%$ of $\% \mathrm{EWL}$ and $26.7 \%$ had DM2. One subject did not have control of SAH postoperatively and presented $58.7 \%$ of $\% \mathrm{EWL}$.

Because of a high proportion of control of these comorbidities postoperatively, logistic regression analysis was possible only with preoperative data. Among 12 gene polymorphisms analyzed, 5HT2C (rs3813929) and UCP3 (rs1800849) had influence on DM2 prevalence. In the $5 H T 2 C$ gene, subject carriers of the $\mathrm{T}$ allele had a five times greater chance of DM2 compared to CC genotype. In UCP3 gene, CC genotype had three times greater chance of DM2 compared with $\mathrm{T}$ allele carriers (Table 2). However, there was no prevalence of 5-HT2C ( rs3813929) and UCP3 (rs1800849) gene polymorphisms among diabetic subjects who obtained or did not obtain the control of DM2 postoperatively (Table 3 ).

\section{DISCUSSION}

This study investigated the association of 12 gene polymorphisms related to obesity on the prevalence of $\mathrm{SAH}$ and DM2 during the preoperative period and 1 year after RYGB surgery in obese women. Our main finding indicated that 5-HT2C ( $\mathrm{rs} 3813929)$ and UCP3 (rs1800849) gene polymorphisms were associated with the prevalence of DM2 in obese women candidates for bariatric surgery.

Table 1. Characteristics of subject study

\begin{tabular}{|c|c|}
\hline Variables & Median (min-max) \\
\hline Age (years) & $34(20-50)$ \\
\hline Age at onset of obesity (years) & $18(0-40)$ \\
\hline Preoperative BMI (kg/m²) & $46(33-73)$ \\
\hline BMI postoperatively (kg/m²) & $30(20-55)$ \\
\hline \%EWL 1 year postoperatively & $69(37-119)$ \\
\hline \multicolumn{2}{|l|}{ DM2 preoperative $-n(\%)$} \\
\hline Yes & $76(22)$ \\
\hline No & $275(88)$ \\
\hline \multicolumn{2}{|l|}{ DM2 1 year postoperative $-n(\%)$} \\
\hline Yes & $10(2.8)$ \\
\hline No & $341(97.2)$ \\
\hline \multicolumn{2}{|l|}{ SAH preoperative $-n(\%)$} \\
\hline Yes & $201(57)$ \\
\hline No & $150(43)$ \\
\hline \multicolumn{2}{|l|}{ SAH 1 year postoperative $-n(\%)$} \\
\hline Yes & $01(0.3)$ \\
\hline No & $350(99.7)$ \\
\hline \multicolumn{2}{|l|}{ Family history of obesity $-n(\%)$} \\
\hline Yes & $279(79.5)$ \\
\hline No & $72(20.5)$ \\
\hline \multicolumn{2}{|l|}{ Skin Color $-n(\%)$} \\
\hline Black & $52(14.8)$ \\
\hline White & $226(64.4)$ \\
\hline Parda & $73(20.8)$ \\
\hline \multicolumn{2}{|l|}{ Education - $n(\%)$} \\
\hline Middle and High School (incomplete) & $123(35)$ \\
\hline High School (complete) and superior & $228(65)$ \\
\hline \multicolumn{2}{|l|}{ Previous pregnancies $-n(\%)$} \\
\hline Yes & $263(74.9)$ \\
\hline No & $88(25.1)$ \\
\hline
\end{tabular}

$n=351$. BMI: body mass index; \%EWL: percentage of excess weight loss. 
Table 2. Values of odds ratio (OR) and $95 \%$ confidence interval (95\% Cl) for diabetes mellitus type 2 (DM2) and systemic arterial hypertension (SAH) before and after bariatric surgery, according to each gene polymorphism

\begin{tabular}{|c|c|c|c|c|c|c|c|c|}
\hline \multirow[b]{2}{*}{ Gene Polymorphism } & \multirow{2}{*}{ Genotype } & \multirow{2}{*}{$n(\%)$} & \multicolumn{3}{|c|}{ DM2 Preoperative } & \multicolumn{3}{|c|}{ SAH Preoperative } \\
\hline & & & OR & (95\% Cl) & $p$-value & OR & (95\% Cl) & $p$-value \\
\hline \multirow[t]{2}{*}{ GHRL rs26802 } & $\mathrm{CC}$ & $35(10)$ & 1.00 & & \multirow{2}{*}{0.921} & 1.00 & & \multirow{2}{*}{0.563} \\
\hline & $\mathrm{CA}+\mathrm{AA}$ & $316(90)$ & 1.045 & $(0.436-2.507)$ & & 1.244 & (0.593-2.609) & \\
\hline \multirow[t]{2}{*}{ GHSR rs572169 } & GG & $211(60)$ & 1.00 & & \multirow{2}{*}{0.547} & 1.00 & & \multirow{2}{*}{0.443} \\
\hline & $\mathrm{GA}+\mathrm{AA}$ & $140(40)$ & 0.722 & $(0.250-2.085)$ & & 1.441 & $(0.566-3.667)$ & \\
\hline \multirow[t]{2}{*}{ LEP rs7799039 } & AA & $53(15)$ & 1.00 & & \multirow{2}{*}{0.318} & 1.00 & & \multirow{2}{*}{0.274} \\
\hline & $A G+G G$ & $298(85)$ & 0.652 & $(0.282-1.508)$ & & 0.712 & $(0.388-1.307)$ & \\
\hline \multirow[t]{2}{*}{ LEPR rs 1137101} & GG & $73(21)$ & 1.00 & & \multirow{2}{*}{0.974} & 1.00 & & \multirow{2}{*}{0.945} \\
\hline & $A G+A A$ & $278(79)$ & 0.989 & $(0.514-1.902)$ & & 1.019 & $(0.596-1.742)$ & \\
\hline \multirow[t]{2}{*}{ 5-HT2C rs3813929 } & ТT/CT & $87(25)$ & 1.00 & & \multirow{2}{*}{0.001} & 1.00 & & \multirow{2}{*}{0.556} \\
\hline & CC & $264(75)$ & 0.251 & $(0.109-0.578)$ & & 1.164 & $(0.702-1.928)$ & \\
\hline \multirow[t]{2}{*}{ UCP2 rs659366 } & $\Pi$ & $49(14)$ & 1.00 & & \multirow{2}{*}{0.505} & 1.00 & & \multirow{2}{*}{0.884} \\
\hline & $\mathrm{CT}+\mathrm{CC}$ & $302(86)$ & 1.330 & (0.574-3.082) & & 1.056 & $(0.511-2.181)$ & \\
\hline \multirow[t]{2}{*}{ UCP2 rs660339 } & AA & $49(14)$ & 1.00 & & \multirow{2}{*}{0.238} & 1.00 & & \multirow{2}{*}{0.675} \\
\hline & $A G+G G$ & $302(86)$ & 0.568 & $(0.222-1.452)$ & & 1.167 & $(0.567-2.405)$ & \\
\hline \multirow[t]{2}{*}{ UCP3 rs1800849 } & CC & $54(15)$ & 1.00 & & \multirow{2}{*}{0.019} & 1.00 & & \multirow{2}{*}{0.128} \\
\hline & $\mathrm{CT}+\mathrm{TT}$ & $297(85)$ & 0.305 & $(0.113-0.821)$ & & 0.624 & $(0.341-1.144)$ & \\
\hline \multirow[t]{2}{*}{ SH2B1 rs7498665 } & GG & $223(64)$ & 1.00 & & \multirow{2}{*}{0.594} & 1.00 & & \multirow{2}{*}{0.946} \\
\hline & $A G+A A$ & $294(84)$ & 0.815 & $(0.385-1.726)$ & & 0.980 & $(0.544-1.765)$ & \\
\hline TAS1R2 rs35874116 & $\mathrm{CC}+\mathrm{CT}$ & $184(52)$ & 1.00 & & 7 700 & 1.00 & & 0023 \\
\hline & $\pi$ & $167(48)$ & 1.706 & $(0.626-1.850)$ & 0.190 & 1.019 & (0.658-1.579) & 0.933 \\
\hline TAS1R2 rs9701796 & $\mathrm{GG}+\mathrm{CG}$ & $117(33)$ & 1.00 & & & 1.00 & & \\
\hline & CC & $234(67)$ & 0.761 & $(0.428-1.354)$ & 0.353 & 1.252 & (0.788-1.989) & 0.041 \\
\hline FTO rs9939609 & AA & $71(20)$ & 1.00 & & 011 & 1.00 & & 0050 \\
\hline & $A T+\pi$ & $280(80)$ & 0.963 & $(0.492-1.882)$ & 0.911 & 0.595 & $(0.348-1.017)$ & 0.050 \\
\hline
\end{tabular}

$n=351$. Variables with adjustments for age, skin color, preoperative BMl, previous pregnancy and age at onset of obesity.

Table 3. Prevalence of gene polymorphism for 5-HT2C (rs3813929) and UCP3 (rs1800849) between diabetic subjects who obtained or did not obtain the control of DM2 after bariatric surgery

\begin{tabular}{|c|c|c|c|c|c|c|}
\hline Response & $\mathrm{CT}+\mathrm{CC}$ & $\mathrm{CT}+\mathrm{CT}$ & $\mathrm{CT}+\mathrm{TT}$ & $\mathrm{CC}+\mathrm{CC}$ & $\mathrm{CC}+\mathrm{CT}$ & $\mathrm{CC}+\mathrm{TT}$ \\
\hline Yes & $1 / 65$ & $8 / 58$ & $4 / 62$ & $7 / 59$ & $22 / 44$ & $24 / 42$ \\
\hline No & $0 / 10$ & $1 / 9$ & $1 / 9$ & $1 / 9$ & $3 / 7$ & $4 / 6$ \\
\hline p-value* & 0.868 & 1.000 & 0.985 & 1.000 & 1.000 & 0.999 \\
\hline
\end{tabular}

${ }^{\star}$ Fisher's exact test.

This knowledge might be important in identifying, according to genetic variability, subjects who are at higher risk of DM2, because it is not obesity per se that is the lethal factor, but it's associated chronic diseases. Thus, the analysis of 5-HT2C (rs3813929) and UCP3 (rs1800849) gene polymorphism may theoretically define individualized and preventive measures for DM2 in obese women on a waiting list for bariatric surgery.
Unlike the results of other studies (18-23), the current study did not find an association of GHRL (rs26802), UCP2 (rs659366), FTO (rs9939609), LEP (rs7799039), and LEPR (rs1137101) gene polymorphisms with DM2. These controversies, far from discouraging the study of the effects of gene polymorphisms, instigate a deepening of this knowledge, which takes into account the characteristics 
of the populations and the interactions between the different gene polymorphisms.

Regarding 5-HT2C gene polymorphism results, serotonin plays an important role in the nervous system, such as sleep regulation, body temperature, appetite and mood, among others (24). Thus, low levels of serotonin or problems in the signaling with the receptor have been linked to an increased desire to eat sweets and carbohydrates (25), which may explain in part the association of 5-HT2C gene polymorphism (rs3813929) with the prevalence of DM2 observed in our study.

Similarly, other studies reported that subjects carrying the T allele from 5-HT2C gene polymorphism (rs3813929) were associated with greater chances of DM2. Kring and cols. (26), investigating Caucasian young men, observed an association of $\mathrm{T}$ allele from 5-HT2C gene polymorphism with glucose and acute insulin response. On the other hand, Iordanidou and cols. (27) observed that $\mathrm{T}$ allele frequency was lower in diabetic subjects compared to nondiabetic subjects.

In the present study, the UCP3 gene was also associated with prevalence of DM2, specifically the polymorphism rs 1800849 . The UCP3 protein is involved in promoting fatty acid oxidation in skeletal muscle and it indirectly influences glucose metabolism (28). In addition, UCP3 regulates the production of reactive oxygen species in the mitochondria (28), a factor that has established an association of this protein with DM2, because oxidative stress pathways play a key role in the development of this chronic disease (29).

In this study, women carrying the CC genotype on UCP3 gene polymorphism (rs1800849) showed three times more chance of DM2 compared to allele $\mathrm{T}$ carriers. Corroborating our data, Meirhaeghe and cols. (30) showed that UCP3 gene polymorphism (rs1800849) was related to DM2 on a French cohort, and $\mathrm{T}$ allele carriers presented lower risk.

Regarding data 1 year postoperatively, the 12 gene polymorphisms investigated in our study showed no effect on the control/remission of SAH and DM2. Among the diabetic women in this study, 13\% did not obtain the control of this chronic disease; thus, it is plausible to hypothesize that there are a possible genetic factors involved in the lack of this response postoperatively. On the other hand, considering that 1 year postoperatively is a relatively short time period, it is important to do a long-term investigation ( $>2$ years) to determine these responses.
Although the molecular and genetic comprehension of DM2 has advanced rapidly, much of the knowledge remains unknown. Adding to this, the number of bariatric surgeries has risen as an effective treatment option for obesity and its associated comorbidities. Thus, more studies are necessary to investigate the effects of surgical and non-surgical intervention for weight loss and remission of DM2, while larger numbers of subjects, a wider range of gene polymorphism, and analyzing a later postoperative time, could better elucidate these questions.

Genetic association studies are relevant to determine the risk of chronic diseases on a specific population and to improve the medical and nutritional treatment. These results enable an individualization of the treatment according to genetic variability. The current study investigates 12 obesity-related gene polymorphisms in obese women candidates for bariatric surgery.

In summary, subjects with $\mathrm{T}$ allele from 5 -HT2C gene polymorphism (rs3813929) had five times greater chance of DM2, and the CC genotype from UCP3 gene polymorphism (rs1800849) had three times greater chance of DM2, in the preoperative period. Our results indicate that 5-HT2C and UCP3 gene polymorphism was related to prevalence of DM2 among Brazilian obese women candidates for bariatric surgery.

Disclosure: no potential conflict of interest relevant to this article was reported.

\section{REFERENCES}

1. Global Burden of Disease Study 2013 Collaborators. Global, regional, and national incidence, prevalence, and years lived with disability for 301 acute and chronic diseases and injuries in 188 countries, 1990-2013: a systematic analysis for the Global Burden of Disease Study 2013. Lancet. 2015;386(9995):743-800.

2. Malik VS, Willett WC, Hu FB. Global obesity: trends, risk factors and policy implications. Nat Rev Endocrinol. 2013;9(1):13-27.

3. LuY, Loos RJF. Obesity genomics: assessing the transferability of susceptibility loc across diverse populations. Genome Medicine. 2013;5(55):1-15.

4. Attia J, loannidis JP, Thakkinstian A, McEvoy M, Scott RJ, Minelli $C$, et al. How to use an article about genetic association: A: Background concepts. JAMA. 2009;301(1):74-81.

5. Bauer F, Elbers CC, Adan RA, Loos RJ, Onland-Moret NC, Grobbee $D E$, et al. Obesity genes identified in genome-wide association studies are associated with adiposity measures and potentially with nutriente-specific food. Am J Clin Nutr. 2009;90(4):951-9.

6. RankinenT, Sarzynski MA, Ghosh S, Bouchard C. Are there genetic paths common to obesity, cardiovascular disease outcomes, and cardiovascular risk factors?. Circ Res. 2015;116(5):909-22.

7. Rankinen T, Zuberi, A, Chagnon YC, Weisnagel SJ, Argyropoulos G, Walts B, et al. The Human obesity gene map: the 2005 update. Obesity (Silver Spring). 2006;14(4):529-644. 
8. Xu X, Zeng H, Xiao D, Zhou H, Liu Z. Genome wide association study of obesity. Zhong Nan Da Xue BaoYi Xue Ban. 2013;38(1):95100.

9. Tan LJ, Zhu H, He H, Wu KH, Li J, Chen XD, et al. Replication of 6 obesity genes in a meta-analysis of genome-wide association studies diverse ancestries. Plos One. 2014;9(5):e96149.

10. Neff KJ, le Roux CW. Bariatric surgery: the indications in metabolic disease. Dig Surg. 2014;31(1):6-12.

11. Benoit SC, Hunter TD, Francis DM, De La Cruz-Munoz N. Use of bariatric outcomes longitudinal database (BOLD) to study variability in patient success after bariatric surgery. Obes Surg. 2014;24(6):936-43.

12. de Luis DA, Pacheco D, Aller R, González Sagrado M, Izaola O, Terroba MC, et al. Influence of -55CT polymorphism of UCP3 gene on surgical results of biliopancreatic diversion. Obes Surg. 2010;20(7):895-9.

13. de Luis DA, Aller R, Conde R, Izaola O, Pacheco D, Sagrado MG, et al. Effects of RS9939609 gene variant in FTO gene on weight loss and cardiovascular risk factors after biliopancreatic diversion surgery. J Gastrointest Surg. 2012;16(6):1194-8.

14. Gibson RS. Nutritional assessment: a laboratory manual. New York: Oxford University Press; 1993.

15. Metropolitan height and weight tables. Stat Bul Metrop Live Found. 1983;64(1):3-9.

16. Chobanian AV, Bakris GL, Black HR, Cushman WC, Green LA, Izzo JLJr, et al.; Joint National Committe on Prevention, Detection, Evaluation, and Treatment of High Blood Pressure. National Heart, Lung, and Blood Institute; National High Blood Pressure Education Program Coordinating Committe. Seventh report of Joint National Committee on Prevention, Detection, Evaluation, and Treatment of High Blood Pressure. Hypertension. 2003;42(6):1206-52.

17. American Diabetes Association. Diagnosis and classification of diabetes mellitus. Diabetes Care. 2013;36:S67-74.

18. Gaukrodger N, Mayosi BM, Imrie H, Avery P, Baker M, Connell $\mathrm{JM}$, et al. A rare variant of the leptin gene has large effects on blood pressure and carotid intima-medial thickness: a study of 1428 individuals in 248 families. J Med Gent. 2005;42(6):474-8.

19. Salopuro T, Pulkkinen L, Lindström J, Eriksson JG, Valle TT, Hämäläinen $\mathrm{H}$, et al.; Finish Diabetes Prevention Study Group. Genetic variation in leptin receptor gene is associated with type
2 diabetes and body weight: The Finnish Diabetes Prevention Study. Int J Obes (Lond). 2005;29(10):1245-51.

20. Gueorguiev M, Lecoeur C, Meyre D, Benzinou M, Mein CA, Hinney $A$, et al. Association studies on ghrelin and ghrelin receptor gene polymorphisms with obesity. Obesity (Silver Spring) 2009;17(4):745-54.

21. Salopuro T, Pulkkinen $L$, Lindström J, Kolehmainen M, Tolppanen AM, Eriksson JG, et al. Variation in the UCP2 and UCP3 genes associates with abdominal obesity and serum lipids: the Finnish Diabetes Prevention Study. BMC Med Genet. 2009;10:94.

22. Roszkowska-Gancarz M, Kurylowicz A, Polosak J, Mossakowska M, Franek E, Puzianowska-Kuznicka M. Functional polymorphisms of leptin and leptin receptor genes are associated with longevity and with the risk of myocardial infarction and type 2 diabetes mellitus. Endokrynol Pol. 2014;65(1):11-6.

23. Xi B, Takeuchi F, Meirhaeghe A, Kato N, Chambers JC, Morris AP, et al.; DIAGRAM Consortium, AGEN-T2D Consortium, SAT2D Consortium. Associations of genetic variants in-near body mass index-associated genes with type 2 diabetes: a systematic metaanalysis. Clin Endocrinol (Oxf). 2014;81(5):702-10.

24. Mohammad-Zadeh LF, Moses L, Gwaltney-Brant SM. Serotonin: a review. J Ver Pharmacol Ther. 2008;31(3):187-99.

25. Wurtman RJ, Wurtman JJ. Brain serotonin, carbohydrate-craving, obesity and depression. Obes Res. 1995;4:477S-80S.

26. Kring SI, Werge T, Holst C, Toubro S, Astrup A, Hansen T, et al. Polymorphisms of serotonin receptor $2 \mathrm{~A}$ and $2 \mathrm{C}$ genes and COMT in relation to obesity and type 2 diabetes. PLoS One. 2009;4(8):e6696.

27. Iordanidou M, Tavridou A, Vasiliadis MV, Arvanitidis KI, Petridis $\mathrm{J}$, Christakidis D, et al. The -759C-T polymorphism of 5-HT2C receptor is associated with type 2 diabetes in male and female Caucasians. Pharmacogenet Genomics. 2008;18(2):153-9.

28. Giralt M, Villarroya F. Mitochondrial Uncoupling and the Regulation of Glucose Homeostasis. Curr Diabets Rev. 2016 Feb 17. [Epub ahead of print].

29. Liu J, Li J, Wang CM. The role of uncoupling proteins in diabetes mellitus. J Diabetes Res. 2013;2013:585897.

30. Meirhaeghe A, Amouyel P, Helbecque N, Cottel D, Otabe S, Froguel $P$, et al. An uncoupling protein 3 gene polymorphism associated with lower risk of developing type II diabetes and with athetogenic lipid profile in a French cohort. Diabetologia. 2000;43(11):1424-8. 